\title{
Pengaruh Tambahan Penghasilan Pegawai terhadap Kinerja Pegawai dengan Employee Engagement sebagai Variabel Mediasi
}

\author{
Tiara Nanuru* \\ Universitas Khairun, Ternate \\ Abdullah W. Jabid \\ Universitas Khairun Ternate \\ Ida Hidayanti \\ Universitas Khairun Ternate \\ Email: tiara96.tn@gmail.com
}

\begin{abstract}
Abstrak
Penelitian ini bertujuan untuk menguji pengaruh tambahan penghasilan pegawai terhadap kinerja pegawai dengan employee engagement sebagai variabel mediasi. Total sebanyak 100 tanggapan yang berhasil dikumpulkan melalui penyebaran kuesioner kepada pegawai Badan Kepegawaian Daerah (BKD) dan Badan Pengembangan Sumber Daya Manusia (BPSDM) Provinsi Maluku Utara dengan menggunakan teknik purposive sampling. Teknik analisis yang digunakan dalam penelitian ini adalah Partial Least Square-Structural Equation Modeling (PLS-SEM) dengan bantuan aplikasi SmartPLS versi 3.3. Hasil analisis menunjukkan bahwa tambahan penghasilan pegawai berpengaruh positif dan signifikan terhadap employee engagement, namun tidak berpengaruh signifikan terhadap kinerja pegawai. Employee engagement berpengaruh positif dan signifikan terhadap kinerja pegawai. Employee engagement mampu memediasi secara positif dan signifikan pengaruh tambahan penghasilan pegawai terhadap kinerja pegawai.
\end{abstract}

Kata Kunci :Tambahan Penghasilan Pegawai, Employee Engagement, Kinerja Pegawai

\section{Pendahuluan}

Undang-undang Nomor 5 Tahun 2014 tentang Aparatur Sipil Negara (ASN) hadir sebagai bentuk reformasi birokrasi pemerintah Indonesia dalam upaya transformasi birokrasi dari rule-based bureaucracy (administrasi berbasis kepegawaian) pada tahun 2013 menuju performance-based bureaucracy (manajemen SDM) pada tahun 2018 dan akan membentuk dynamic governance (pengembangan potensi Human Capital) pada tahun 2025. Sejalan dengan reformasi birokrasi maka manajemen Aparatur Sipil Negara (ASN) juga berubah dari administrasi kepegawaian, menuju ke pembangunan Human Capital.

Mempersiapkan Aparatur Sipil Negara (ASN) sebagai human capital yang menjadi penggerak pembangunan dilakukan dengan membentuk manajemen kinerja yang lebih baik. Manajemen kinerja menjadi strategi pemerintah untuk menciptakan pegawai yang memiliki kompetensi tinggi dan mencapai kinerja dalam penyelenggaraan birokrasi yang efektif dan efisien.

Menurut Simanjutak (2011), kinerja yang baik tidak terbentuk dengan sendirinya. Kinerja pegawai dipengaruhi beberapa faktor yaitu kualitas dan kemampuan pegawai, sarana pendukung dan supra sarana. Kualitas dan kemampuan pegawai merupakan faktor intrinsik pegawai yang mendukung kinerja seperti etos kerja, motivasi kerja, sikap mental, kondisi fisik 
pegawai dan tingkat pendidikan/pelatihan. Sedangkan sarana pendukung berhubungan dengan kesejahteraan pegawai seperti upah/gaji, jaminan sosial dan keamanan kerja.

Kemampuan dan kualitas pegawai berkaitan dengan faktor internal individu yang tercermin pada sikap dan perilaku pegawai dalam melaksanakan perannya. Berkaitan dengan sikap dan perilaku pegawai, konsep employee engagement menjadi perhatian dalam praktek manajemen sumber daya manusia beberapa dekade terakhir. Saks (2006) berpendapat bahwa employee engagement merupakan cerminan pegawai yang secara sadar mengikat diri dengan pekerjaan. Pegawai yang engaged mengekspresikan dirinya secara fisik, kognitif dan emosional selama melaksanakan perannya.

Employee engagement mendatangkan serangkaian manfaat yang menjadi kekuatan tersendiri dalam mencapai tujuan organisasi. Sehingga menjadi penting bagi setiap organisasi untuk memperhatikan variabel employee engagement dalam peningkatan kinerja pegawainya. Hal ini juga didukung dengan serangkaian penelitian juga membuktikan bahwa employee engagement berpengaruh positif terhadap kinerja pegawai (Anitha, 2014; Widyastuti dan Raharja, 2018; Citra dan Sagala, 2019; Arifin et al., 2019).

Lebih lanjut, kinerja pegawai juga dipengaruhi oleh sarana pendukung yang berkaitan dengan kesejahteraan pegawai secara finansial. Salah satu caranya dengan memberikan insentif bagi pegawai. Handoko (2002) mengemukakan bahwa insentif adalah perangsang yang ditawarkan kepada para karyawan untuk melaksanakan kerja sesuai atau lebih tinggi dari standar-standar yang telah ditetapkan. Sehingga, pemberian insentif diharapkan dapat memotivasi pegawai untuk bekerja lebih baik dalam melaksanakan perannya sehingga menghasilkan kinerja individu yang maksimal. Salah satu bentuk insentif yang diberikan pemerintah adalah tambahan penghasilan. Tambahan penghasilan diberikan kepada pegawai negeri sipil dengan pertimbangan objektif dan memperhatikan kemampuan keuangan daerah. Pemberian tambahan penghasilan pegawai juga ditujukan untuk meningkatkan kesejahteraan pegawai dan meningkatkan kinerja pegawai.

Berkaitan dengan hal tersebut, beberapa penelitian terdahulu yang dilakukan oleh Madjid (2016), Piani et al., (2015), dan Rohim dan Budhiasa (2019) menunjukkan bahwa tambahan penghasilan pegawai memiliki pengaruh signifikan terhadap kinerja pegawai. Di sisi lain, penelitian serupa juga dilakukan oleh Hadi et al., (2019) namun menemukan hasil yang berbeda dimana tambahan penghasilan pegawai tidak berpengaruh signifikan terhadap kinerja pegawai.

Berdasarkan pada kesenjangan hasil penelitian terdahulu yang telah diuraikan sebelumnya, penelitian ini dimaksudkan untuk menguji lebih lanjut pengaruh tambahan penghasilan pegawai terhadap kinerja pegawai dengan mempertimbangkan employee engagement sebagai pemediasi di Badan Kepegawaian Daerah (BKD) dan Badan Pengembangan Sumber Daya Manusia (BPSDM) Provinsi Maluku Utara.

\section{Landasan Teori dan Pengembangan Hipotesis}

\section{Kinerja}

Mangkunegara (2006) mendefinisikan kinerja atau prestasi kerja sebagai hasil kerja secara kualitas dan kuantitas yang dicapai oleh seorang pegawai dalam melaksanakan tugasnya sesuai dengan tanggung jawab yang diberikan kepadanya Mangkunegara. Sejalan dengan pendapat tersebut Sedarmayanti (2011) menambahkan bahwa kinerja merupakan terjemahan dari performance yang berarti hasil kerja seorang pekerja, sebuah proses manajemen atau suatu organisasi secara keseluruhan, dimana hasil kerja tersebut harus dapat ditunjukkan buktinya secara konkrit dan dapat diukur (dibandingkan dengan standar yang telah ditentukan). 


\section{Tambahan Penghasilan Pegawai}

Menurut Peraturan Gubernur Provinsi Maluku Utara Nomor 25 Tahun 2019, Tambahan Penghasilan Pegawai (TPP) adalah penghasilan yang diterima di luar gaji dan tunjangan berdasarkan hasil penilaian kinerja pegawai. Pemberian tambahan penghasilan bagi pegawai juga diharapkan dapat meningkatkan kinerja dan kesejahteraan pegawai sehingga dapat dikatakan bahwa bentuk insentif yang diterima pegawai negeri sipil adalah tambahan penghasilan pegawai.

\section{Employee Engagement}

Schaufeli et al (2002) mendefinisikan employee engagement sebagai keadaan pikiran yang positif dan memuaskan yang berhubungan dengan pekerjaan yang ditandai dengan semangat (vigor), dedikasi (dedication), dan pemaknaan penuh (absorption). Vigor mengacu pada tingkat energi dan ketahanan yang tinggi, kemauan untuk menginvestasikan tenaga, tidak mudah lelah, dan kegigihan dalam menghadapi kesulitan. Dedication mengacu pada sikap pegawai yang mengarah pada pemaknaan yang tinggi terhadap pekerjaan, perasaan antusias dan bangga dengan pekerjaan, merasa terinspirasi dan tertantang dengan pekerjaannya. Absorption mengacu pada pegawai yang memiliki perasaan bahagia yang mendalam pada pekerjaannya, dan kesulitan untuk meninggalkannya sehingga pegawai merasa waktu berlalu begitu cepat disekitarnya.

\section{Kerangka Pikir Penelitian}

Penelitian ini dimaksudkan untuk menguji pengaruh tambahan penghasilan pegawai (TPP) terhadap kinerja pegawai dengan employee engagement sebagai pemediasi. Adapun kerangka pikir penelitian dapat digambarkan sebagai berikut:

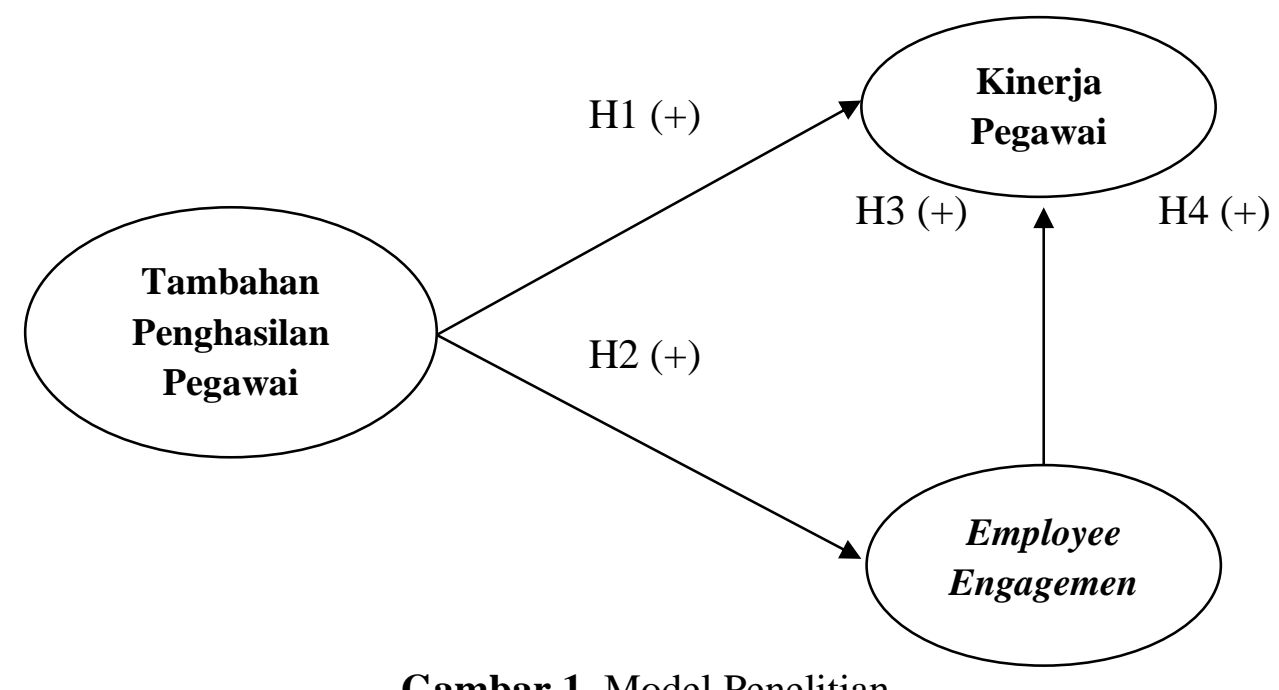

Gambar 1. Model Penelitian

\section{Hipotesis Penelitian}

sebagai berikut:

$\boldsymbol{H}_{1}$ : Tambahan penghasilan pegawai (TPP) berpengaruh positif dan signifikan terhadap kinerja pegawai.

$\boldsymbol{H}_{2}$ : Tambahan penghasilan pegawai (TPP) berpengaruh positif dan signifikan terhadap employee engagement.

$\boldsymbol{H}_{3}$ : Employee engagement berpengaruh positif dan signifikan terhadap kinerja pegawai 
Tiara Nanuru, Abdullah W. Jabid, Ida Hidayanti

$\boldsymbol{H}_{4}$ : Employee engagement memediasi hubungan antara tambahan penghasilan pegawai dan kinerja pegawai.

\section{Metode Penelitian}

Penelitian ini menggunakan metode kuantitatif untuk menganalisis pengaruh variabel tambahan penghasilan pegawai (TPP) terhadap kinerja pegawai dengan employee engagement sebagai pemediasi di Badan Kepegawaian Daerah (BKD) dan Badan Pengembangan Sumber Daya Manusia (BPSDM) Provinsi Maluku Utara. Populasi dalam penelitian ini adalah seluruh pegawai Badan Kepegawaian Daerah (BKD) dan Badan Pengembangan Sumber Daya Manusia (BPSDM) Provinsi Maluku Utara yang berjumlah sebanyak 2.324 pegawai. Adapun penentuan julah sampel dalam penelitian ini didasarkan pada pendapat Hair et al (2011) yang menyarankan penentuan jumlah sampel untuk teknik analisis PLS-SEM adalah jumlah indikator reflektif dikalikan dengan 5. Oleh karena jumlah indikator reflektif dalam penelitian ini berjumlah 20 indikator, maka jumlah sampel yang digunakan adalah sebanyak 100 responden. Teknik pengumpulan data dalam penelitian ini dilakukan dengan penyebaran kuesioner kepada pegawai Badan Kepegawaian Daerah (BKD) dan Badan Pengembangan Sumber Daya Manusia (BPSDM) Provinsi Maluku Utara yang berisi seperangkat pertanyaan terkait variabel yang diteliti dengan menggunakan teknik purposive sampling.

Indikator variabel tambahan penghasilan pegawai (TPP) diadaptasi dari Umbeang et al (2020) yang terdiri dari 4 item pertanyaan; indikator variabel employee engagement diadaptasi dari Schaufeli dan Bakker (2004) yang terdiri dari 7 item pertanyaan; indikator variabel kinerja pegawai diadaptasi dari Widiyana (2015) yang terdiri dari 7 item pertanyaan. Adapun skala pengukuran yang digunakan untuk setiap variabel yang digunakan dalam penelitian adalah skala Likert 5 poin. Setelah semua data yang diperlukan telah terkumpul, data tersebut selanjutnya dianalisis menggunakan tekni analisis Partial Least Square-Structural Equation Modeling (PLS-SEM) dengan bantuan aplikasi SmartPLS versi 3.3. Terdapat dua evaluasi dalam teknik analisis PLS-SEM, yakni evaluasi model pengukuran (outer model) yang dimaksudkan untuk menguji validitas dan reliabilitas konstruk, dan evaluasi model struktural (inner model) yang ditujukan untuk pengujian hipotesis dan kemampuan prediktif model penelitian (Hair et al., 2011).

\section{Hasil Penelitian dan Pembahasan}

\section{Hasil Evaluasi Model Pengukuran (outer model)}

Evaluasi model pengukuran dilakukan untuk mengevaluasi validitas dan reliabilitas konstruk Adapun terdapat beberapa kriteria yang digunakan untuk mengevaluasi model pengukuran, yakni 1) convergent validity yang dilihat dari nilai outer loading yang harus lebih besar dari 0.60, dan nilai Average Variance Extracted (AVE) yang harus lebih besar dari 0.50, 2) discriminant validity yang dilihat dari nilai Fornell-Larcker dimana nilai akar AVE untuk setiap variabel laten harus lebih besar dari korelasinya dengan variabel laten lain, 3) nilai cronbach's alpha dan composite reliability yang harus lebih besar dari 0.60 dan 0.70 (Hair et al., 2011). Berdasarkan pada hasil analisis menggunakan SmartPLS versi 3.3 sebagaimana yang ditunjukkan pada Gambar 2, diketahui bahwa terdapat dua item yang dinyatakan tidak valid dengan nilai loading yang lebih kecil dari 0.60, yakni item TPP1 dan EE7. Oleh karena itu, model pengukuran harus dimodifikasi dengan mengeliminasi setiap item yang tidak valid. 


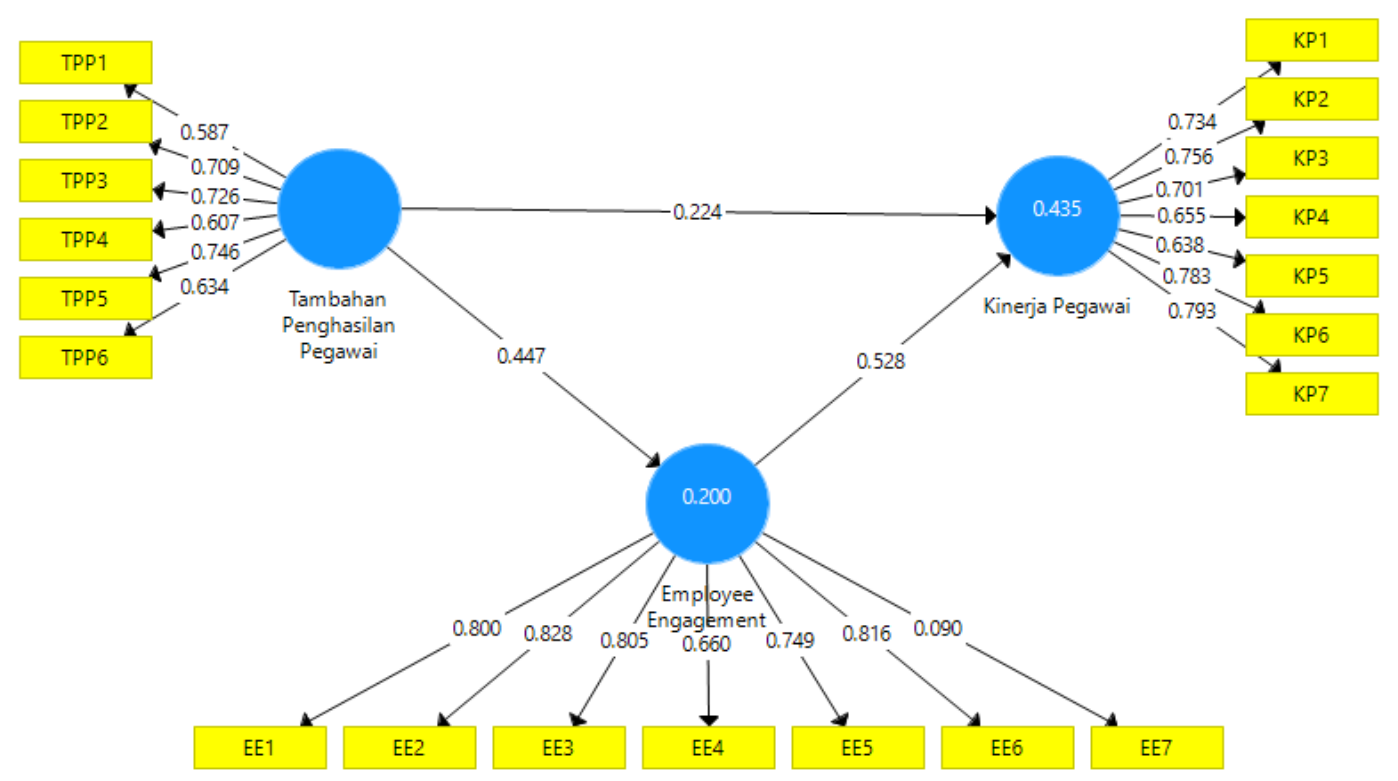

Gambar 2. Hasil Evaluasi Model Pengukuran (outer model) Sumber: Output SmartPLS versi 3.3

Setelah melewati dua kali modifikasi, diperoleh model pengukuran yang telah memenuhi kriteria. Sebagaimana yang ditunjukkan pada Gambar 3, seluruh item memiliki nilai loading yang lebih besar dari 0.60 sehingga dapat dikatakan bahwa seluruh item pertanyaan untuk masing-masing variabel yang digunakan dalam penelitian ini adalah valid dan dapat digunakan untuk tahap analisis selanjutnya.

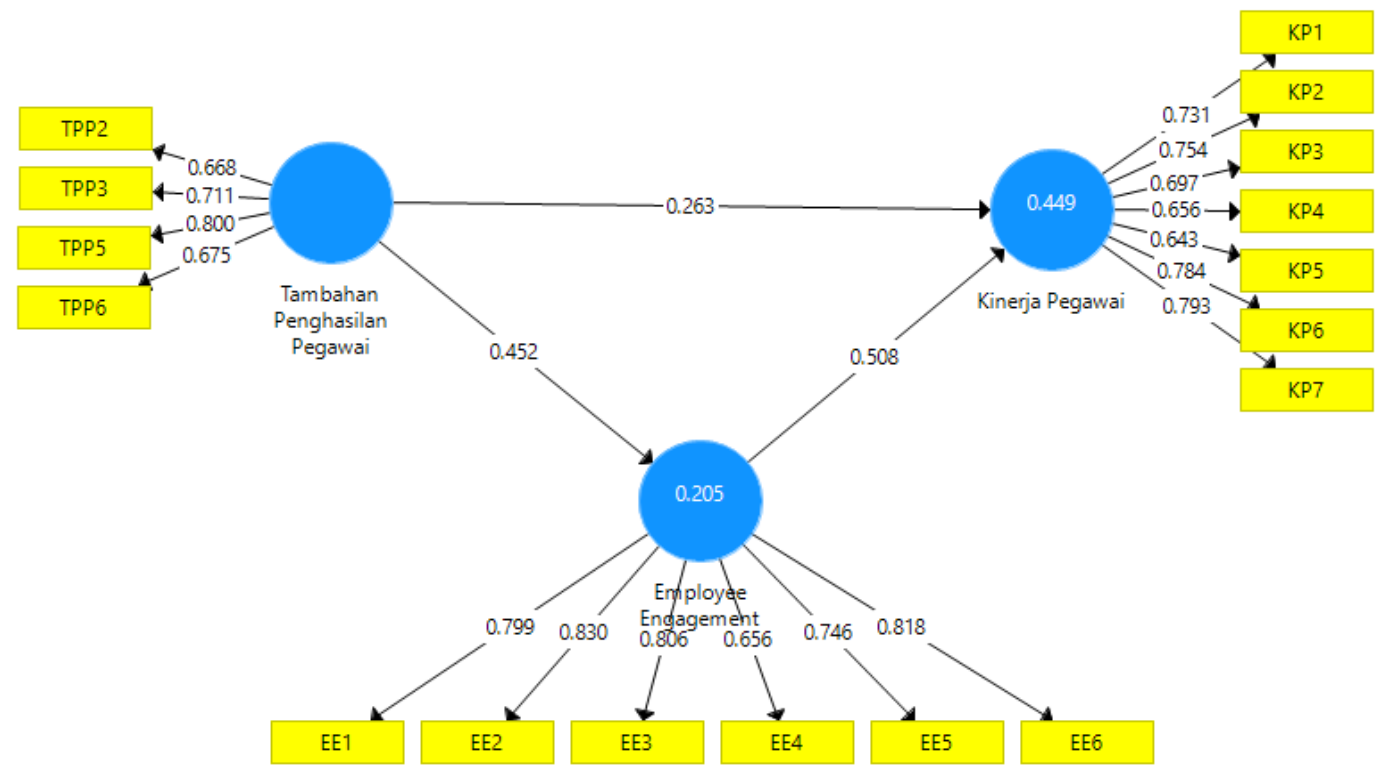

Gambar 3. Hasil Evaluasi Model Pengukuran (outer model) Setelah Modifikasi

Sumber: Output SmartPLS versi 3.3

Untuk pengujian discriminant validity yang dilihat dari nilai Fornell-Larcker, sebagaimana yang ditunjukkan pada Tabel 1, diketahui bahwa nilai akar AVE untuk setiap variabel laten lebih besar dari korelasinya dengan variabel laten lain sehingga dapat disimpulkan bahwa setiap variabel telah memenuhi syarat discriminant validity. 
Tiara Nanuru, Abdullah W. Jabid, Ida Hidayanti

Tabel 1. Nilai Fornell-Larcker Criterion

\begin{tabular}{|l|c|c|c|}
\hline \multicolumn{1}{|c|}{ Variabel } & $\begin{array}{c}\text { Employee } \\
\text { Engagement }\end{array}$ & $\begin{array}{c}\text { Kinerja } \\
\text { Pegawai }\end{array}$ & $\begin{array}{c}\text { Tambahan } \\
\text { Penghasilan } \\
\text { Pegawai }\end{array}$ \\
\hline Employee Engagement & $\mathbf{0 . 7 7 8}$ & - & - \\
\hline Kinerja Pegawai & 0.627 & $\mathbf{0 . 7 2 5}$ & - \\
\hline $\begin{array}{l}\text { Tambahan Penghasilan } \\
\text { Pegawai }\end{array}$ & 0.452 & 0.493 & $\mathbf{0 . 7 1 5}$ \\
\hline
\end{tabular}

Sumber: Output SmartPLS versi 3.3

Terakhir, sebagaimana yang ditunjukkan pada Tabel 3, diketahui bahwa seluruh variabel laten memiliki nilai AVE $>0.50$, nilai cronbach's alpha $>0,60$, dan nilai composite reliability $>0.70$ sehingga dapat disimpulkan bahwa seluruh variabel yang digunakan dalam penelitian ini memiliki reliabilitas yang baik dan telah memenuhi syarat yang ditentukan.

Tabel 2. Nilai AVE, Cronbach's Alpha, dan Composite Reliability

\begin{tabular}{|l|c|c|c|}
\hline \multicolumn{1}{|c|}{ Variabel } & $\begin{array}{c}\text { Average } \\
\text { Variance } \\
\text { Extracted (AVE) }\end{array}$ & $\begin{array}{c}\text { Cronbach's } \\
\text { Alpha }\end{array}$ & $\begin{array}{c}\text { Composite } \\
\text { Reliability }\end{array}$ \\
\hline $\begin{array}{l}\text { Tambahan Penghasilan } \\
\text { Pegawai }\end{array}$ & 0.512 & 0.698 & 0.807 \\
\hline Employee Engagement & 0.602 & 0.869 & 0.902 \\
\hline Kinerja Pegawai & 0.525 & 0.848 & 0.885 \\
\hline
\end{tabular}

Sumber: Output SmartPLS versi 3.3

\section{Hasil Evaluasi Model Struktural (inner model)}

Evaluasi model struktural digunakan untuk mengetahui signifikansi pengaruh variabel independen terhadap variabel dependen melalui uji t dan juga dengan melihat koefisien jalur (path coefficient) masing-masing hubungan. Suatu variabel dapat dikatakan memiliki pengaruh yang signifikan apabila nilai $p$-value yang lebih kecil dari 0,05 dan nilai $t$-statistics yang lebih besar dari 1,96 .

Tabel 3. Hasil Pengaruh Langsun dan Tidak Langsung

\begin{tabular}{|l|c|c|c|c|c|}
\hline \multicolumn{1}{|c|}{ Pengaruh } & $\begin{array}{c}\text { Koefisien } \\
\text { Jalur }\end{array}$ & $\begin{array}{c}\text { Sample } \\
\text { Mean }\end{array}$ & $\begin{array}{c}\text { Std. } \\
\text { Deviation }\end{array}$ & $\begin{array}{c}\boldsymbol{T} \text { - } \\
\text { Statistics }\end{array}$ & $\begin{array}{c}\boldsymbol{P} \\
\text { Values }\end{array}$ \\
\hline TPP -> KP & 0.263 & 0.273 & 0.154 & 1.711 & 0.087 \\
\hline TPP -> EE & 0.452 & 0.478 & 0.102 & 4.422 & 0.000 \\
\hline EE -> KP & 0.508 & 0.509 & 0.135 & 3.759 & 0.000 \\
\hline $\begin{array}{l}\text { TPP -> EE -> } \\
\text { KP }\end{array}$ & 0.230 & 0.246 & 0.092 & 2.507 & 0.012 \\
\hline $\begin{array}{l}\mathrm{R}^{2} \text { Kinerja Pegawai: 0.449 } \\
\mathrm{R}^{2} \text { Employee Engagement: } 0.205\end{array}$ & & & \\
\hline
\end{tabular}

Sumber: Output SmartPLS versi 3.3 
Berdasarkan pada hasil analisis sebagaimana yang ditunjukkan pada tabel di atas, diketahui nilai koefisien determinasi $\left(\mathrm{R}^{2}\right)$ untuk variabel kinerja pegawai sebesar 0.449. Hal ini berarti bahwa sebesar $44.9 \%$ varians dari variabel kinerja pegawai dapat dijelaskan oleh variabel tambahan penghasilan pegawai (TPP) dan employee engagement, sedangkan sisanya dijelaskan oleh variabel lain yang tidak termasuk dalam penelitian ini. Selain itu, juga diketahui nilai koefisien determinasi $\left(\mathrm{R}^{2}\right)$ untuk variabel employee engagement sebesar 0.205 , yang berarti bahwa sebesar $20.5 \%$ varians dari variabel employee engagement dapat dijelaskan oleh variabel tambahan penghasilan pegawai (TPP), sedangkan sisanya dijelaskan oleh variabel lain yang tidak termasuk dalam penelitian ini.

\section{Pengujian Hipotesis}

\section{Pengaruh Tambahan Penghasilan Pegawai (TPP) terhadap Kinerja Pegawai}

Berdasarkan pada Tabel 3, diperoleh nilai koefisien jalur untuk hipotesis satu, pengaruh tambahan penghasilan pegawai (TPP) terhadap kinerja pegawai, yang bernilai positif, yakni 0.263 yang berarti bahwa apabila tambahan penghasilan pegawai mengalami peningkatan sebesar satu poin, maka kinerja pegawai juga akan mengalami peningkatan sebesar 0.263. Selain itu, diketahui $T$-statistic untuk hipotesis satu adalah sebesar 1.771 yang lebih kecil dari $1.96(1.771<1.96)$ dengan $p$ value sebesar 0.087 yang lebih besar dari $0.05(0.087>0.05)$. Oleh karena itu, dapat disimpulkan bahwa hipotesis satu dalam penelian ini ditolak, dimana tambahan penghasilan pegawai diketahui tidak berpengaruh signifikan terhadap kinerja pegawai.

\section{Pengaruh Tambahan Penghasilan Pegawai terhadap Employee Engagement}

Berdasarkan pada Tabel 3, diperoleh nilai koefisien jalur untuk hipotesis dua, pengaruh tambahan penghasilan pegawai (TPP) terhadap employee engagement, yang bernilai positif, yakni 0.452 yang berarti bahwa apabila tambahan penghasilan pegawai mengalami peningkatan sebesar satu poin, maka employee engagement juga akan mengalami peningkatan sebesar 0.452. Selain itu, diketahui T-statistic untuk hipotesis dua adalah sebesar 4.422 yang lebih besar dari 1.96 (4.422>1.96) dengan $p$ value sebesar 0.000 yang lebih kecil dari 0.05 $(0.000<0.05)$. Oleh karena itu, dapat disimpulkan bahwa hipotesis dua dalam penelian ini diterima, dimana tambahan penghasilan pegawai diketahui memiliki pengaruh positif dan signifikan terhadap employee engagement.

\section{Pengaruh Employee Engagement terhadap Kinerja Pegawai}

Berdasarkan pada Tabel 3, diperoleh nilai koefisien jalur untuk hipotesis tiga, pengaruh employee engagement terhadap kinerja pegawai, yang bernilai positif, yakni 0.508 yang berarti bahwa apabila employee engagement mengalami peningkatan sebesar satu poin, maka kinerja pegawai juga akan mengalami peningkatan sebesar 0.508. Selain itu, diketahui $T$-statistic untuk hipotesis tiga adalah sebesar 3.759 yang lebih besar dari 1.96 (3.759>1.96) dengan $p$ value sebesar 0.000 yang lebih kecil dari $0.05(0.000<0.05)$. Oleh karena itu, dapat disimpulkan bahwa hipotesis tiga dalam penelian ini diterima, dimana employee engagement diketahui memiliki pengaruh positif dan signifikan terhadap kinerja pegawai.

\section{Pengaruh Tambahan Penghasilan Pegawai terhadap Kinerja Pegawai melalui Employee Engagement sebagai Pemediasi}

Berdasarkan pada Tabel 3, diperoleh nilai koefisien jalur untuk hipotesis empat, pengaruh tambahan penghasilan pegawai terhadap kinerja pegawai melalui employee engagement sebagai pemediasi, yang bernilai positif, yakni 0.230 yang berarti bahwa employee 
Tiara Nanuru, Abdullah W. Jabid, Ida Hidayanti

engagement memediasi secara positif pengaruh tambahan penghasilan pegawai terhadap kinerja pegawai. Selain itu, diketahui T-statistic untuk hipotesis empat adalah sebesar 2.507 yang lebih besar dari 1.96 (2.507>1.96) dengan $p$ value sebesar 0.012 yang lebih kecil dari 0.05 $(0.012<0.05)$. Oleh karena itu, dapat disimpulkan bahwa hipotesis empat dalam penelian ini diterima, dimana employee engagement diketahui mampu memediasi secara positif dan signifikan pengaruh tambahan penghasilan pegawai terhadap kinerja pegawai.

\section{Kesimpulan}

Berdasarkan pada hasil analisis dan pengujian hipotesis, maka dapat ditarik kesimpulan sebagai berikut. Pertama, tambahan penghasilan pegawai dalam penelitian ini diketahui tidak memiliki pengaruh langsung terhadap kinerja pegawai. Hal ini mengindikasikan bahwa besar kecilnya tambahan penghasilan yang diberikan kepada pegawai tidak akan berdampak pada peningkatan atau penurunan kinerja pegawai. Kedua, tambahan penghasilan pegawai diketahui memiliki pengaruh langsung terhadap employee engagement, yang berarti bahwa penambahan atau pengurangan tambahan penghasilan pegawai akan berdampak pada peningkatan atau penurunan employee engagement. Ketiga, employee engagement diketahui memiliki pengaruh langsung terhadap kinerja pegawai, yang berarti bahwa peningkatan atau penurunan employee engagement akan berdampak pada peningkatan atau penurunan kinerja pegawai. Terakhir, employee engagement diketahui mampu memediasi pengaruh tambahan penghasilan pegawai terhadap kinerja pegawai, yang berarti bahwa semakin besar pengaruh tambahan penghasilan terhadap employee engagement, maka semakin besar pula pengaruh employee engagement terhadap kinerja pegawai.

\section{Daftar Pustaka}

Anitha, J. (2014). Determinants of employee engagement and their impact on employee performance. International journal of productivity and performance management.

Arifin, Z., Nirwanto, N., \& Manan, A. (2019). Improving the effect of work satisfaction on job performance through employee engagement. International Journal of MultiDiscipline Science (IJ-MDS), 2(1), 1-9.

Citra, S., \& Sagala, E. J. (2019). The Effect Of Employee Engagement And Compensation Toward Employee Performance. eProceedings of Management, 6(2).

Hadi, S., Barlian, N. A., \& Muttaqien, F. (2018). Pengaruh Disiplin Kerja Melalui Sistem Informasi Presensi Pemerintah Kabupaten Lumajang (Siperlu) Dan Tambahan Penghasilan Pegawai (TPP) terhadap Kinerja Pegawai Negeri Sipil di Dinas Kesehatan Kabupaten Lumajang. Journal of Organization and Business Management, 1(4), 76-80.

Hair, J. F., Ringle, C. M., \& Sarstedt, M. (2011). PLS-SEM: Indeed a silver bullet. Journal of Marketing theory and Practice, 19(2), 139-152.

Handoko, H. (2002) Manajemen Personalia dan Sumber Daya Manusia. Yogyakarta: BPFE

Madjid, M. (2016). Pengaruh Tambahan Penghasilan Pegawai (TPP) dan Kemampuan Kerja terhadap Kinerja Pegawai pada Badan Perencanaan, Penelitian dan Pembangunan Daerah (Bappeda) Kabupaten Morowali. Katalogis, 4(8).

Mangkunegara, A.P. (2006) Manajemen Sumber Daya Manusia Perusahaan. Bandung: Remaja Rosdakarya.

Peraturan Gubernur Maluku Utara No 25 Tahun 2019 tentang Pemberian Tambahan Penghasilan Pegawai Negeri Sipil di Lingkungan Pemerintah Provinsi Maluku Utara Tahun Anggaran 2020. 
Piani, H. R., Widyastuti, Y., \& Cadith, J. (2015). Pengaruh Tambahan Penghasilan Pegawai Negeri Sipil (Tp-Pns) Terhadap Kinerja Pegawai Eselon III Dan IVDi Dinas Kesehatan Kota Serang (Doctoral dissertation, Universitas Sultan Ageng Tirtayasa).

Rohim, A., \& Budhiasa, I. G. S. (2019). Organizational culture as moderator in the relationship between organizational reward on knowledge sharing and employee performance. Journal of Management Development.

Saks, A. M. (2006). Antecedents and consequences of employee engagement. Journal of managerial psychology.

Schaufeli, W. B., Salanova, M., González-Romá, V., \& Bakker, A. B. (2002). The measurement of engagement and burnout: A two sample confirmatory factor analytic approach. Journal of Happiness studies, 3(1), 71-92.

Schaufeli, W. B., \& Bakker, A. B. (2004). Job demands, job resources, and their relationship with burnout and engagement: A multi-sample study. Journal of Organizational Behavior: The International Journal of Industrial, Occupational and Organizational Psychology and Behavior, 25(3), 293-315.

Sedarmayanti. (2011) Manajemen Sumber Daya Manusia, Reformasi Birokrasi dan Manajemen Pegawai Negeri Sipil (cetakan kelima). Bandung: PT Refika Aditama.

Simanjuntak, P. J. (2011). Manajemen dan Evaluasi Kinerja (Edisi 3). Jakarta: Lembaga Penerbit FEUI.

Umbeang, F., Rorong, A., \& Plangiten, N. (2020). Pengaruh Tambahan Penghasilan Pegawai Terhadap Kinerja Dinas Pekerjaan Umum Dan Tata Ruang Kabupaten Kepulauan Talaud. Jurnal Administrasi Publik, 6(94).

Widiana, M. E. (2015). Variabel dan Indikator yang Mempengaruhi Komitmen dan Kinerja Organisasi Pemerintahan. Universitas Bhayangkara Surabaya.

Widyastuti, N., \& Rahardja, E. (2018). Analisis Pengaruh Stres Kerja, Kompensasi, dan Employee Engagement terhadap Kinerja Pegawai (Studi pada Pegawai PDAM Tirta Moedal Kota Semarang). Diponegoro Journal of Management, 7(1), 55-65. 